\title{
A COMPUTER SYSTEM FOR ACQUISITION AND ANALYSIS OF MEASUREMENT DATA FOR A SKEW ROLLING MILL IN MANUFACTURING STEEL BALLS
}

\author{
Marcin Buczaj $^{1}$, Andrzej Sumorek ${ }^{2}$ \\ ${ }^{1}$ Lublin University of Technology, Department of Electrical Engineering and Electrotechnologies, Lublin, Poland, ${ }^{2}$ Lublin University of Technology, Department of Structural \\ Mechanics, Lublin, Poland \\ Abstract. The article presents the concept and capabilities of a computer system for analysing measurement data for a skew rolling mill used to produce \\ steel balls. The computer system for data acquisition and analysis consists of cooperating systems designed to perform control and measurement tasks \\ during the operation of a skew rolling mill. Their main task is to collect and record data related to the measured physical parameters of the batch rolling \\ process. This system registers the current and analyses the radial forces and torque acting on the rolled element by the rolling tool. The process of data \\ acquisition, analysis and archiving is carried out by means of an NI USB 6009 measuring card together with the attached systems of transducers and force \\ and torque sensors and a computer with an installed application. The measurement application was developed in the LabVIEW environment. \\ The application algorithm is based on the state machine architecture and enables the configuration of measurement elements and technical parameters, \\ checking the functioning of the control and measurement system and the acquisition and archiving of measurement data.
}

Keywords: data acquisition, measurement techniques, force and torque measurement, programming environments

\section{KOMPUTEROWY SYSTEM DO AKWIZYCJI I PRZETWARZANIA DANYCH POMIAROWYCH DLA WALCARKI SKOŚNEJ PRZY WYTWARZANIU KUL STALOWYCH}

Streszczenie. W artykule została przedstawiona koncepcja oraz zaprezentowane możliwości komputerowego systemu do analizy danych pomiarowych dla walcarki skośnej wykorzystanej do wytworzenia kul stalowych. Komputerowy system akwizycji $i$ analizy danych to wspótpracujace ze soba uktady przeznaczone do realizacji zadań kontrolno-pomiarowych podczas pracy walcarki skośnej. Ich głównym zadaniem jest zbieranie $i$ rejestracja danych zwiąanych z mierzonymi parametrami fizycznymi procesu walcowania skośnego wsadu. Układ ten umożliwia bieżaca rejestrację $i$ analize sit promieniowych $i$ momentu obrotowego działajacego na walcowany element przez narzędzie walcujace. Realizacja procesu akwizycji, analizy i archiwizacji danych odbywa się za pomoca karty pomiarowej NI USB 6009 wraz dołaczonymi do niej układami przetworników i czujników sity i momentu obrotowego oraz komputera z zainstalowana aplikacją. Aplikacja pomiarowa została opracowania w środowisku LabVIEW. Algorytm aplikacji został oparty o architekturę maszyny stanu $i$ umożliwia konfigurację elementów pomiarowych i parametrów technicznych, sprawdzenie funkcjonowania układu kontrolno-pomiarowego oraz akwizycje i archiwizacje danych pomiarowych.

Słowa kluczowe: akwizycja danych, techniki pomiarowe, pomiar siły i momentu obrotowego, środowiska programistyczne

\section{Introduction}

Metal forming processes, including rolling, are widely used in the engineering industry and are particularly important in the metallurgical industry. Rolling processes are used to produce balls, rings, pipes, as well as more complex shapes such as drills bits. This is due to the numerous advantages of this method of processing and forming metal products [3]. The main advantages of this process are:

- high efficiency,

- material saving,

- small amount of production waste,

- high precision of formed elements,

- low production costs and limited energy consumption of the process.

One of the basic products obtained in the rolling process is balls. Balls, especially steel ones, are used for the production of rolling bearings, as well as other machine and equipment components. Balls can also be used as tools to process other materials. They are often used as grinders in ball mills and are used for grinding: metal ores, coal, cement, sand and other materials $[2,7]$.

Generally, the processes of plastic forming are quite well known. However, there is a constant need to develop new processing techniques. Knowing the technical and physical parameters of production processes is particularly important for the teams of constructors and inventors, where checking one's own ideas and comparing research results with computer calculations and simulations allows to specify the machining process, to determine the most favourable technical parameters and to determine and become acquainted with the parameters of the equipment $[1,4-6,8]$.

Verification of theoretical assumptions concerning the processes of shaping the product is performed by means of specially dimensioned machines equipped with appropriate sensors. The measurement systems used allow the control and monitoring of the current operating parameters of the device and the evaluation of the forming processes. The system for managing, supervising and collecting measurement data should be distinguished by its flexibility and compatibility with other systems enabling data processing. The article presents a computer system for monitoring and archiving measurement data from force and torque sensors developed in the LabVIEW programming environment by National Instruments, cooperating with an NI-USB-6009 measurement card.

\section{Ball rolling process and the structure of a skew rolling mill}

Ball screw rolling in a skew rolling mill consists in forming forgings of balls from a solid bar between two oblique rollers (equipped with screw blanks), with separation of the finished product. Only one ball is formed with each rotation of the rolls $[2,3]$. The process of making balls in a skew rolling machine is shown in Fig. 1.

Screw rolling of forgings in skew rolling mills is one of the most efficient methods of producing this type of semi-finished products. It is characterised by many advantages, which include, among others, small material losses, greater accuracy in relation to forged or cast semi-finished products, easy automation and a favourable structure layout, which improves the strength properties and increases the durability of such shaped products.

The inclined rolling mill used in the research has a segmental structure and consists of a load-bearing frame, drive system, rolling cage and drive transmission system (Fig. 2). Its basic technical parameters are as follows:

- horizontal position of the rollers in the work cage;

- nominal diameter of the rolls: $320 \mathrm{~mm}$;

- working length of the roll barrel: $400 \mathrm{~mm}$;

- $\min / \mathrm{max}$ distance of the rollers' axes: $300 \div 350 \mathrm{~mm}$;

- two rotational speeds of the rolls: $15 \mathrm{rpm}$ and $30 \mathrm{rpm}$;

- nominal torque on one cylinder (at $15 \mathrm{rpm}$ ): $20 \mathrm{kN} \cdot \mathrm{m}$; 
- rated torque on one cylinder (at $30 \mathrm{rpm}$ ): $10 \mathrm{kN} \cdot \mathrm{m}$;

- machine total weight: $17,500 \mathrm{~kg}$;

- rated power of two-speed drive motor: $60 \div 80 \mathrm{~kW}$.

Fig. 3 shows the tools that plasticise the material subjected to the rolling process. In Fig. 4, the output of the process of producing balls in a skew rolling mill is presented.
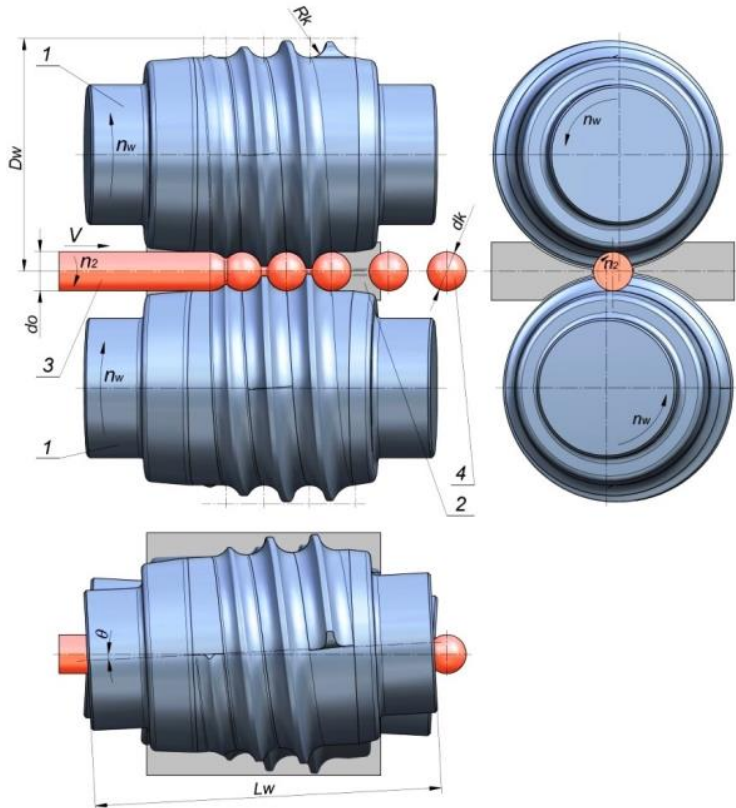

Fig. 1. Diagram of the ball rolling process in a skew rolling mill:1- rollers with screw blanks, 2 - guides, 3 - batch, 4 - shaped ball [2, 3]

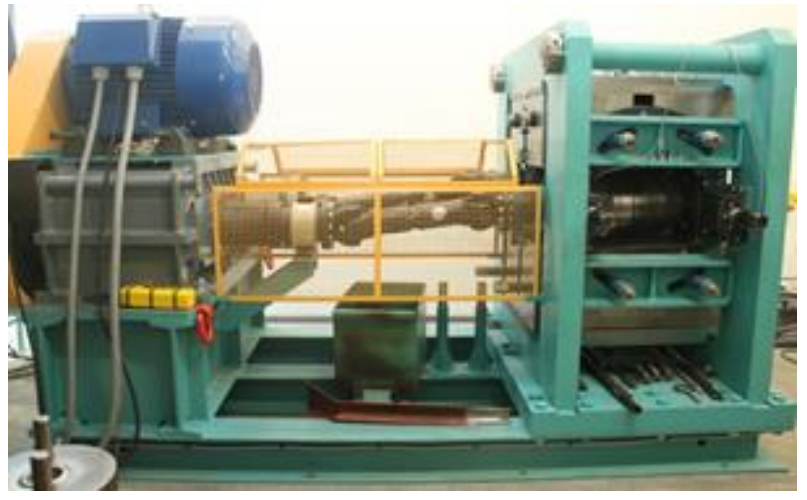

Fig. 2. Skew rolling machine

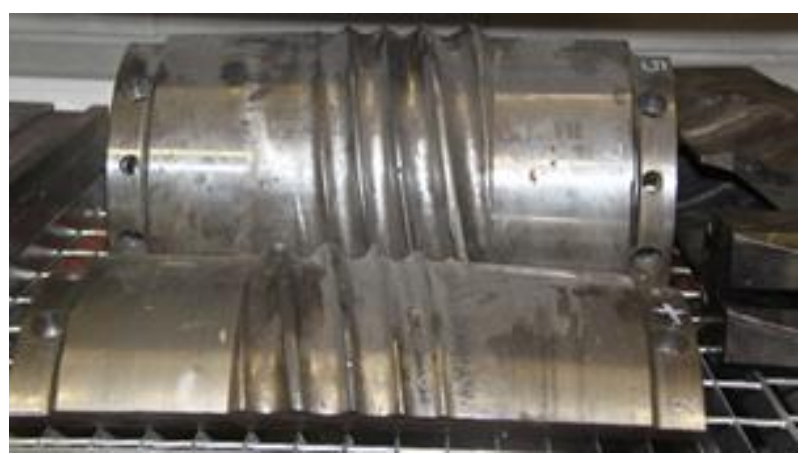

Fig. 3. Tool for producing balls in the process of rolling in a skew rolling machine

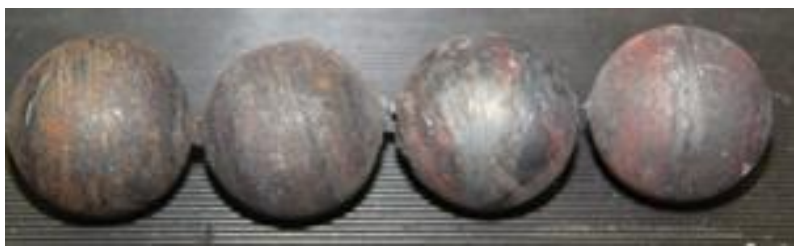

Fig. 4 Balls obtained by processing a metal bar in a skew rolling machine

\section{Characteristics of the measuring system}

The data acquisition system ensures the registration of two or three (depending on the chosen measurement option) technical parameters of the skew rolling process. The choice of the option depends on the type and shape of the processed material. The figures are:

- shaft torque - BCM model 1816 torque sensor;

- radial force on the first working roller - CL-16 strain gauge force sensor with a CL-72U-3U transducer from ZEPWN;

- radial force on the second working roller - CL-16 strain gauge force sensor with a CL-72U-3U transducer from ZEPWN

The 1816 series sensor (Fig. 5), manufactured by BCM, is a non-contact rotary torque transducer with an air bearing among the rotor and stator via to allow the product to function under the immense rotating speed of $6000 \mathrm{rpm}$. It has a $1.5 \mathrm{~mm}$ air gap on the rotor and the stator. Its non-contact feature lowers the maintenance requirements and makes it durable enough for extended utilisation. In addition, it has a 5-2000 $\mathrm{Nm}$ torque capacity transducer, with a $0.5 \%$ fs precision and an output signal of $10 \pm 5 \mathrm{kHz}$ [9].

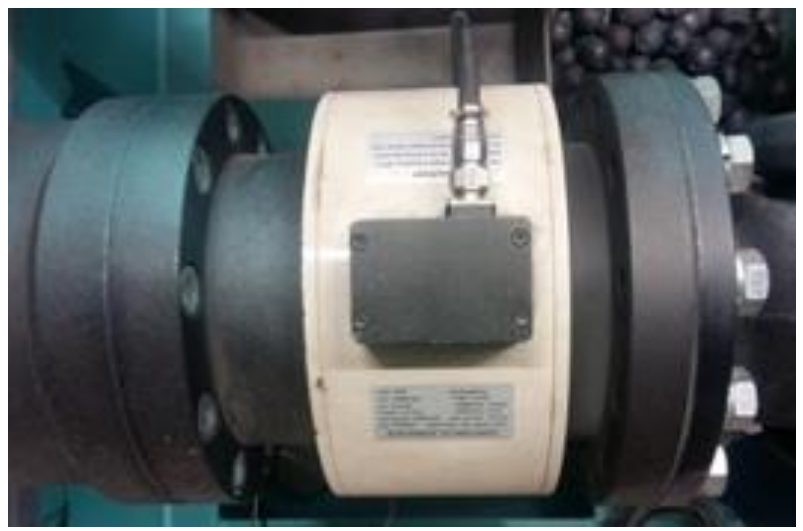

Fig. 5. Model 1816 BCM rotary torque sensor installed on the shaft of a skew rolling machine

The CL16 strain gauge force sensor (Fig. 6) together with the CL 72-3U amplifier from ZEPWN is a sensor designed for measuring static tensile and compressive forces. The sensoramplifier system is characterised by high accuracy in class 0.5 and 1 in a wide range of measurements (from 10\% to $100 \%$ of the measuring range). The system generates a signal in the measuring track in the range from $0 \mathrm{~V}$ to $10 \mathrm{~V} \mathrm{DC}[11,12]$.

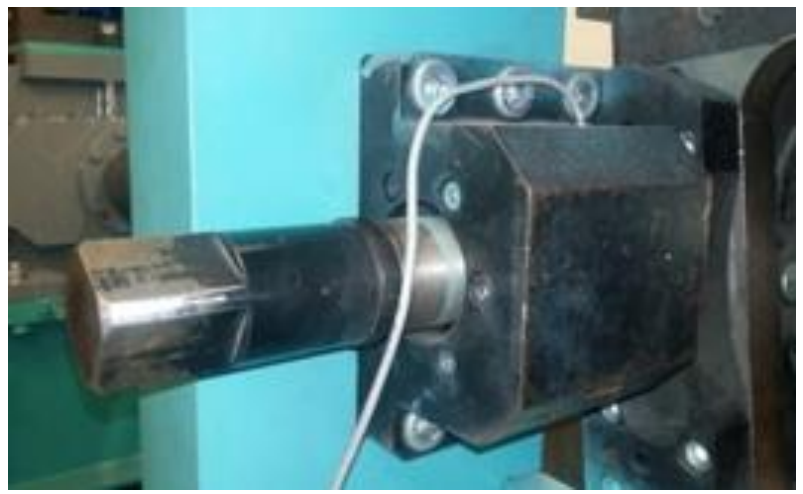

Fig. 6. One of the two tensometric force sensor by ZEPWN mounted on a skew rolling machine

Data recording concerns the recording of 2 physical parameters (torque and radial force) at 3 measurement points. Additionally, the data acquisition system has two reserve channels for connecting additional sensors (e.g. shift sensor). The mutual configuration of the control system elements and data acquisition is presented in Fig. 7. 


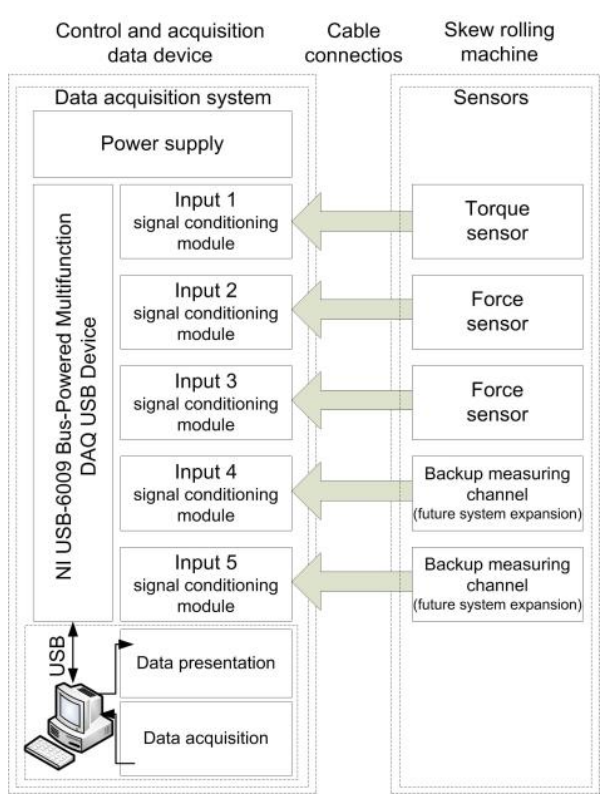

Fig. 7. Schematic diagram of the control and data acquisition system connected to a skew rolling machine

Data from the measurement sensors are collected by a USB-6009 measurement card from National Instruments (Fig. 8). The measurement card allows measurement and generation of both analogue and digital signals. The card is equipped with 8 analogue inputs with a resolution of 13 bits, allowing measurement of voltages from $-10 \mathrm{~V}$ to $10 \mathrm{~V}$ in relation to the ground terminal. There is a possibility of program switching of the voltage measurement method and connecting the inputs in pairs to 14-bit inputs. The card has two independent voltage outputs with a resolution of 12 bits, generating variable voltage values of any shape within the range from $0 \mathrm{~V}$ to $5 \mathrm{~V}$. They are protected against overload by an internal $50 \Omega$ resistor switched on in a series. The maximum sampling frequency of the analogue signals is $48 \mathrm{kS} / \mathrm{s}$. The digital part of the card contains 12 digital connectors in two ports working both as inputs and outputs, and two DC voltage sources of $+2.5 \mathrm{~V}$ and $5 \mathrm{~V}$ and a ground output. The card is also equipped with a counter with a 12-bit resolution [10].

In the measuring system, the signals from the measuring sensors are connected to single-ended voltage inputs on the NI-USB 6009 measuring card working in the range of $\pm 10 \mathrm{~V}$.
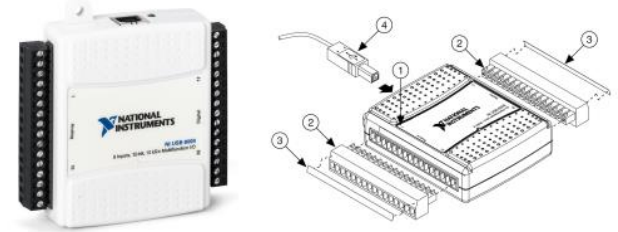

Fig. 8. National Instruments USB-6009 Data Acquisition Card (1 - overlay labe with pin orientation guides, 2 - screw terminal connector plug, 3 - signal label, 4-USB cable

\section{Application for acquisition and presentation of measurement data}

The data acquisition software was implemented in the LabVIEW Professional Development System graphical programming environment (2017, version 17.0f2, 64 bit, National Instruments). The LabVIEW programming environment and the USB-6009 measurement card come from the same manufacturer.

The developed data acquisition system performs the following functions related to the management and monitoring of physical parameters of the diagonal rolling process: configuration and testing of control and measurement system elements, data acquisition during the measurement process, recording and presentation of measurement data and preliminary processing of file data.
The state machine architecture was used to create an algorithm for program operation. This allows, from the user's point of view, to go straight to the selected range of actions. The only exception to this rule is an obligatory declaration of the disk directory in which the hardware settings and measurement results will be stored. Without this initial action, it is not possible to call up other procedures. It is possible to return to these settings and modify them at any time when using the program.

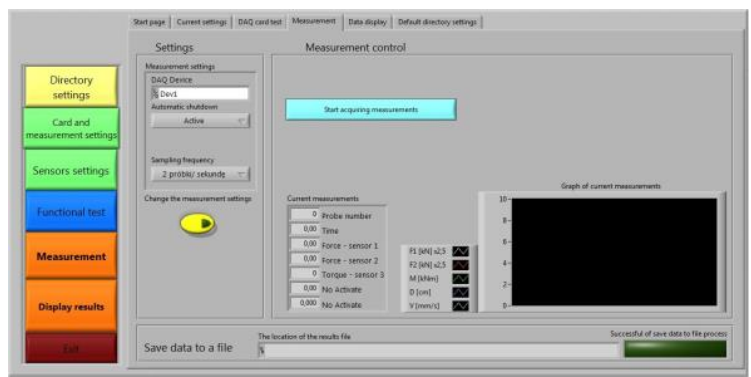

Fig. 9. Measurement process window of the application

Figures 9 and 10 show two front windows of the application panel, in which it is possible to carry out the measurement process and to present current sensor readings and to display previously archived measurement data (Fig. 10).

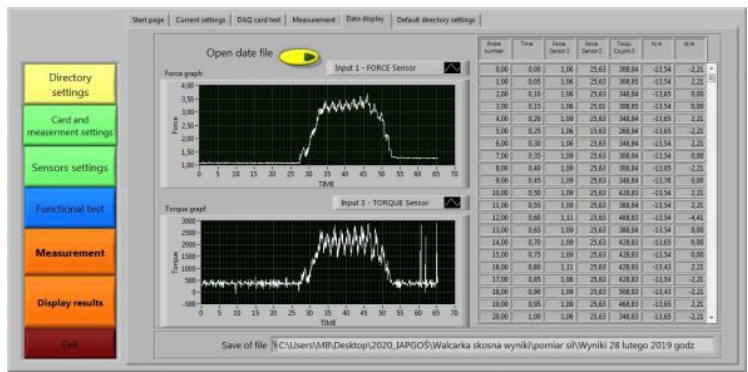

Fig. 10. Data presentation window of the application

The complete measurement procedure with data recording results in storing the measurement data collected from the detection devices in the folder indicated by the user. The values obtained in the current measurement process are available for viewing in graphical and text form in the main program window after selecting the "Displaying results" tab.

Due to the large variety of registered values, the range of measurement values and the amount of data, it is more convenient to view the results in software dedicated to data processing and analysis. The described data acquisition system automatically saves data in files in the *.tsv format (tab separated value), which is transparent and supported by practically every data processing environment. This solution enables system users to further process measurement data in other application programs. It also allows the use of additional mathematical and computational formulas, and thus the comparison of the results obtained with other measurement data or those obtained from modelling and computer simulation processes.

\section{Presentation of measurement data and test results}

A computer system for the acquisition and processing of measurement data for a skew rolling machine is used during the process of manufacturing steel balls in laboratory (testing) conditions using real materials. The practical research included the measurement of two or three signals related to the process of forming and manufacturing steel balls. The number of signals used was related, among others, to the form of the semi-finished products.

An example set of measurement data obtained from the data acquisition system is shown in Fig. 11 (the value of radial force was determined on the basis of data from the ZEPWN company's force sensor, and the value of torque on the basis of the BCM company's torque sensor). 


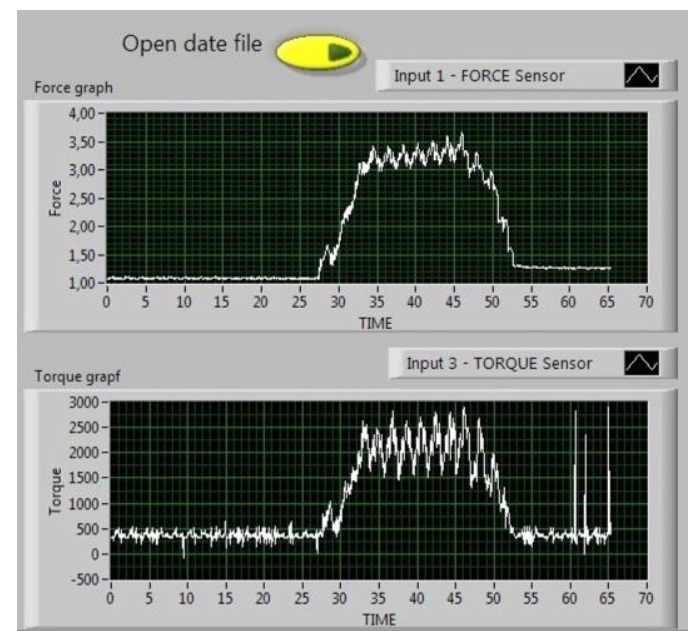

Fig. 11. Measurement data presentation in the application

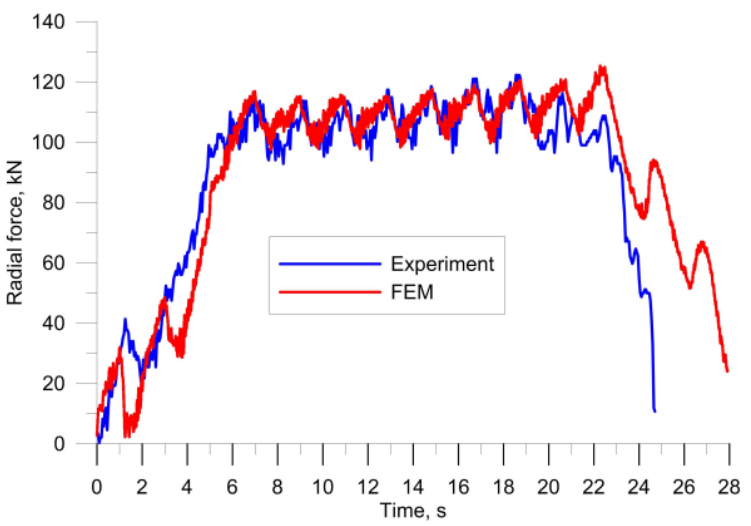

Fig. 12. Comparison of measurement data with FEM simulation (force measurement)

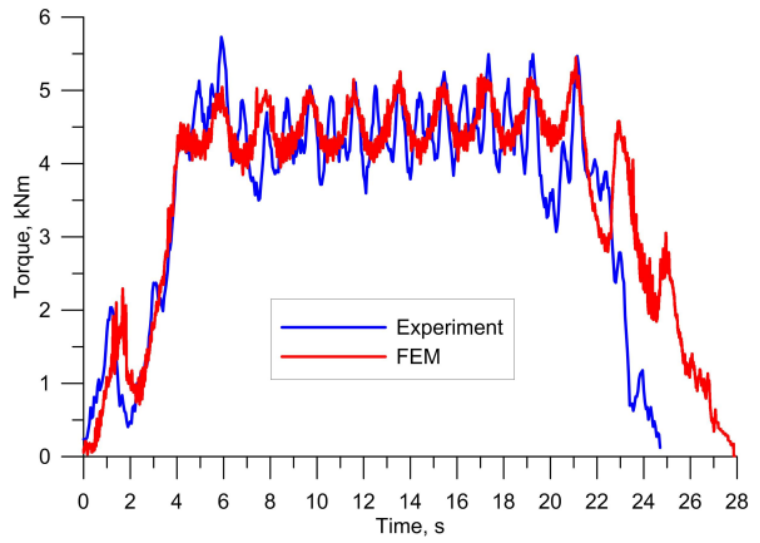

Fig. 13. Comparison of measurement data with FEM simulation (torque measurement)

Measurement data can be edited in popular software (e.g. Microsoft Excel). Thanks to this functionality of the measurement data acquisition system, it is possible to process the measurement data and present them in a program convenient for the user.

One of the research elements aimed at checking the regularity and correctness of the data obtained by means of the measurement system discussed was to check the measurement data received with the calculation data obtained on the basis of FEM simulations (Finite Element Method). The simulations were carried out with the use of the specialized Simufact Forming software (ver. 15). The simulation parameters reflected the real process parameters, that is: tool rotation speed $-30 \mathrm{rpm}$, diameter of the formed ball $40 \mathrm{~mm}$, batch material - steel bar of type C67, and initial batch temperature $-1000^{\circ} \mathrm{C}$. The described model of object was divided into 35,000 elements. The initial size of the element was $1 \mathrm{~mm}$. The eight nodal elements of first-order were used.

The radial force and torque time courses for the sample measurement data and the data obtained from the FEM simulations are shown in Fig. 12 and Fig. 13. Both diagrams show slight mutual deviations and differences between the courses.

\section{Conclusions}

On the basis of a series of tests and measurements related to the process of manufacturing steel balls in a skew rolling mill using a computer system for the acquisition and processing of measurement data, it was found that the system discussed is very useful in practical applications.

The system allows for effective acquisition of measurement data crucial in the determination of significant technical parameters of the forming process during the production of metal balls in a skew rolling mill.

The data obtained by means of the measuring system are consistent and comparable with the calculation data obtained from FEM simulations. A comparative analysis of the material obtained from experimental testing and simulation calculations shows minor differences. These may result from certain general criteria and coefficients adopted in the modelling process.

The measurement system shown allows the measurement data to be archived in such a way that they can be further processed by other external programs. This provides the possibility to increase the analytical capabilities of the measurement data and use them in programs dedicated to the processing of such data.

\section{References}

[1] Filippova M. V., Temlyantsev M. V., Peretyatko V. N., Prudkii E. E.: Rolling of metal balls. Steel in Translation 47, 2014, 435-439 [https://doi.org/10.3103/S0967091217070038].

[2] Gontarz A., Tomczak J., Pater Z., Bulzak T.: Effect of the Forming Zone Length on Helical Rolling Processes for Manufacturing Steel Balls. Materials 18, 2019, 1-13 [https://doi.org/10.3390/ma12182917].

[3] Pater Z., Tomczak J.: Walcowanie śrubowe kul do młynów kulowych Politechnika Lubelska. Lublin 2012.

[4] Pater Z., Tomczak J., Bartnicki J., Lovell M. R., Menezes P. L.: Experimental and numerical analysis of helical-wedge rolling process for producing steel balls. International Journal of Machine Tools \& Manufacture 67, 2013, 1-7 [https://doi.org/10.1016/j.ijmachtools.2012.12.006].

[5] Pater Z., Tomczak J., Bulzak T., Martyniuk S.: A helical wedge rolling process for producing a ball pin. Archives of Civil and Mechanical Engineering 4, 2019 , 1316-1326 [https://doi.org/10.1016/j.promfg.2018.12.039].

[6] Pater Z., Tomczak J.: FEM Modelling of a helical wedge rolling process for axisymmetric parts. Advances in Science and Technology Research Journal 1, 2018, 115-126 [https://doi.org/10.12913/22998624/81767].

[7] Tomczak J., Pater Z., Kazanecki J., Bartnicki J., Chyła P.: Badania procesu kształtowania kul w walcach śrubowych. Mechanik 11, 2012, 927-931.

[8] Yang H., Zhang L., Hu Z. The analysis of the stress and strain in skew rolling. Advanced Materials Research 538-541, 2012, 1650-1653 [https://doi.org/10.4028/www.scientific.net/AMR.538-541.1650].

[9] https://www.directindustry.com/prod/bcm-sensor-technologies-bvba/product56103-659831.html (accessed: 12.11.2020).

[10] National Instruments, USB-6009 Multifunction I/O Device, https://www.ni.com/pl-pl/support/model.usb-6009.html (accessed: 12.11.2020).

[11] Tensometryczny czujnik siły typu CL14U. Karta produktu. ZEPWN Zakład Elektroniki Pomiarowej Wielkości Nieelektrycznych, Marki.

[12] Wzmacniacz CL 72-3U w obudowie. Karta produktu. ZEPWN Zakład Elektroniki Pomiarowej Wielkości Nieelektrycznych, Marki.

\section{Ph.D. Eng. Marcin Buczaj}

e-mail: m.buczaj@pollub.pl

Marcin Buczaj is an academic teacher in the Department of Electrical Engineering and Electrotechnologies of the Faculty of Electrical Engineering and Computer Science of the Lublin University of Technology. Research interests are surveillance systems, security systems, electrical installations, measurement systems and graphical interfaces for measurement systems.

https://orcid.org/0000-0002-7624-1674

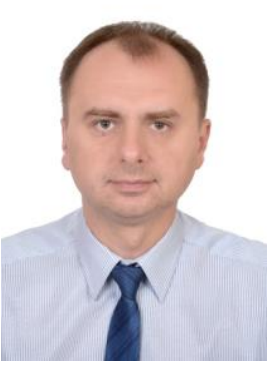

Ph.D. Eng. Andrzej Sumorek

e-mail: a.sumorek@pollub.pl

Andrzej Sumorek is an academic teacher in the Department of Structural Mechanics of the Faculty of Building and Architecture of the Lublin University of Technology.

Research interests are data acquisition, graphical interfaces for measurement systems, energy saving electrotechnologies, electrostatic filters for dust removal.

https://orcid.org/0000-0002-7521-6709

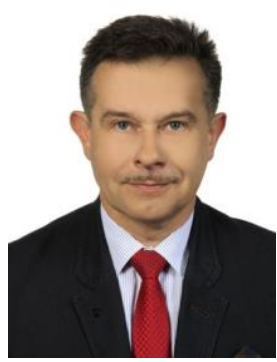

otrzymano/received: 17.11 .2020 